\title{
The Learning Paradox: The Digital Generation Seeks A Personal, Human Voice
}

\author{
Nitza Davidovitch ${ }^{\star}$ (ic \\ Yael Yossel-Eisenbach ${ }^{2}$ \\ ${ }^{\prime}$ Ariel University, Ariel, Israel \\ Email:d.nitza@ariel.ac.il \\ 'Israel College of Applied Science (ICA), Israel
}

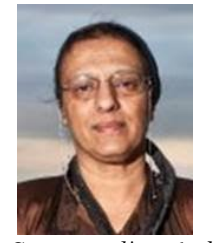

( Corresponding Author

\begin{abstract}
This study examines undergraduate students' perceptions of academic teaching and factors that affect these perceptions, whether social background, secondary education, academic background, or learning habits. The study is based on the findings of a previous study conducted by the authors, which indicated two patterns of learning habits among undergraduate students: those oriented toward the use of digital and technological devices, and those oriented toward the use of traditional technology-resistant means. These learning habits were incorporated as explanatory variables in the current study, which included 772 undergraduate students in 14 disciplines from 37 academic institutions. A complex picture emerges from the research findings. On one hand, students' attitudes toward teaching indicate a preference for teaching that stresses personal rather technological aspects. While students' learning patterns also reflect traditional learning patterns, students do not resist technology: they are exposed to and actively use technologies, both within and outside of the learning context. Moreover, it emerges that traditional learning habits have a formative effect on perceptions of technology-oriented teaching. That is to say, despite a conventional mode of learning and a preference for personal frontal teaching, students appear to subscribe to the notion that academic institutions should be at the cutting edge of teaching technologies. Thus, a gap is identified between students' personal preferences and their perceptions of ideal academic teaching. This gap may stem from issues related to learning and/or from the social and academic climate. Investigation of the gap and of related issues is a recommended subject for future research.
\end{abstract}

Keywords: Teaching, Learning, Academia, Technology, Paradox, Human voice.

Citation | Nitza Davidovitch; Yael Yossel-Eisenbach (2019). The Learning Paradox: The Digital Generation Seeks A Personal, Human Voice. Journal of Education and e-Learning Research, 6(2): Hum 61-68.

History:

Received: 8 November 2018

Revised: 18 January 2019

Accepted: 26 February 2019

Published: 15 April 2019

Licensed: This work is licensed under a Creative Commons

Attribution 3.0 License (cc) EY

Publisher: Asian Online Journal Publishing Group
Contribution/Acknowledgement: Both authors contributed to the conception and design of the study.

Funding: This study received no specific financial support

Competing Interests: The authors declare that they have no conflict of interests.

Transparency: The authors confirm that the manuscript is an honest, accurate, and transparent account of the study was reported; that no vital features of the study have been omitted; and that any discrepancies from the study as planned have been explained.

Ethical: This study follows all ethical practices during writing.

\section{Contents}

1. Introduction

2. Method 64

3. Findings 65

4. Conclusion and Discussion 67

References. 


\section{Contribution of this paper to the literature}

This study contributes to the existing literature by investigating undergraduate students' perceptions of academic teaching and factors that affect these perceptions, whether social background, secondary education, academic background, or learning habits.

\section{Introduction}

\subsection{Shaping the Teaching Perceptions of Students in the Digital Generation}

In recent years, there has been a significant rise and advance in technology and in technology-assisted teaching both in academia and in schools. It is evident that there is a new generation of children, known in the literature as "digital children" and "the web generation", who are surrounded by information and media technologies that include the internet, smartphones, and comprehensive media (Prensky, 2001).

There is an evident difference between this and preceding generations, manifested both in their manners of learning and in their manners of thought and cognition. Children of the internet generation learn actively, through simultaneous experiencing and specializing in the performance of tasks, finding a great deal of information, and communicating with the environment and with many spheres. According to Brown (2002) the knowledge acquisition of this generation is not linear; rather it is characterized by "bricolage", i.e., learning based on outcomes of amateurish and improvised inquiries carried out unprofessionally.

\subsection{Use of Technology in Academic Teaching}

The development of technological tools resulted in a change in academic teaching and required the training of future teachers for technology-assisted teaching from a pedagogical-didactic aspect and from the technical aspect of combining vocal and printed material, in contrast to information conveyed in traditional teaching processes, where information is acquired either by speaking or by means of written material (Yan, 2004).

Despite these trends, the changes occurring in the educational system are usually supported by the government and therefore cannot change without the consent of senior elements who determine policy from the top down. This planning is an essential but not sufficient condition, as it requires the formulation of a vision, setting standards, developing new study programs, and appointing leadership in the institutions and within the entire system (Kozma, 2003).

\subsection{Training Programs for Technology-Assisted Teaching}

In recent years, many programs have been developed on training for technology-assisted teaching in educational institutions. These programs emphasize the development of varied skills, including literacy, information, critical thinking, inquiry and problem solving, communication and teamwork, orientation to selfstudy, ethics, and variety on the web. Lecturers and researchers involved in processes of assimilating information technologies initiated a study examining the current state of affairs in these areas, explored at colleges of education through three dimensions. The first dimension dealt with the training of teacher trainees in technology-assisted teaching, including developing skills and practical experience with this type of teaching. Lecturers and instructors worked by means of modeling, whereby skills for using technology-assisted tools were demonstrated. Moreover, the attitudes of teacher trainees to integrating technology in teaching and learning were examined. The second dimension focused on the pedagogical and professional needs of the teaching staff. Attitudes toward use of technology and of media were examined, as well as the difficulties formed as a result of this change. The third dimension examined the general system of the policy on implementing and assimilating technology in the educational system. Furthermore, this dimension also stressed the organizational structure and the necessary demands for realizing the essential conditions in order to maintain the change (budgets, infrastructure, technical, pedagogical, and management support (Goldstein et al., 2012).

The trends formed in education were manifested in experiments performed in schools throughout San Francisco. In these schools, a new method was applied, in an attempt to implement a new model of technology with the purpose of maximizing learning and helping teachers produce and reach the students' maximal potential. Each student who arrives at school is under surveillance, beginning with the "attendance app" and ending with the direct transfer of all data on that student to a central smart system through which teachers can devise an individually adapted teaching program for each student. As part of this program, students work autonomously, using an iPad and other technological means. Thanks to these advanced technologies that enable acceptance of student data in large quantities, these students receive assignments that are adapted for them by the teachers, according to their study ability and personal goals. The findings of these experiments show that it is very important to develop new technological models in the classrooms, manifested in investing billions of dollars a year in technology-assisted teaching and many technological means (Byrnes, 2015).

\subsection{The Influence and Contribution of Technological Means in Academic Institutions}

The change formed in the technological era had a considerable effect on academia as well, in addition to the schools. In recent years, many students have been coming to class with laptops that enable high access and availability of the internet at all times, including in class. These mobile appliances support active learning by students and suggest another alternative to the traditional notebook, bringing with them as they do a personal study environment in class and outside it. Use of laptops lets students remain connected to study resources even when not at the university, which leads to a learning continuity that is unrelated to time and place. Namely, even at home students can continue to study continuously and successively. Moreover, the contribution of technologyassisted teaching is evident not only in efficient learning by students, rather it also gives the teaching staff a rich and knowledgeable approach to conveying class contents (Campbell and Pargas, 2003; Barak et al., 2006; Kraushaar and Novak, 2010; Mifsud et al., 2013). It is evident that lecturers who refer students to real and relevant information during class generate interesting and wide study experiences for the students (Mishar-Tal et al., 2012). 
The contribution of technological means to classes has positive influences, both on the study level and regarding students' motivation to learn. Nevertheless, despite the many benefits of technological means, there are also negative effects on students, such as the temptation to surf websites unrelated to the class, checking and sending electronic mail, conversations on social networks, entering websites that are not relevant for the contents of the class taught, and attractive games that divert the student's attention (Kraushaar and Novak, 2010; GehlenBaum and Weinberger, 2012).

\subsection{From "Traditional" Teachers to "Virtual" Teachers}

The new technological reforms are evident in the different levels of teaching between traditional teachers and teachers who have begun to utilize the new technological field. Namely, teachers who teach traditionally prepare a prearranged study plan, where they teach preplanned topics. In addition, students who study with traditional teachers are requested to learn and review topics as instructed. However, the study method selected by traditional teachers is applied to all students, i.e., there are no deviations from the general lesson plan. In contrast, teachers who teach in the virtual method let each student choose topics that interest him or her, as well as a suitable study rate, the order of the topics, as well as the scope of learning, according to personal considerations. In addition, the study plan is flexible, as manifested in the permission given to students to complete the course in one month rather than only at the end of the year or of the semester (Eitan, 2006). Moreover, virtual courses are studied individually by means of teacher mediation and instruction via e-mail. There is also shared learning in-group forums, enabling mutual help between students, which creates a "learning community" (Royer, 1997; Idan, 2000; Karniel, 2003).

Notably, unlike traditional teachers virtual teachers are expected to become mentors, i.e., guides, coaches, friends, supporters, counselors, and companions of their students at all times. All this is done in a manner that requires no direct physical encounters with their students (Feinmesser, 2000).

Today, in Israel and elsewhere, there are "online courses" that include a variety of technological means that mediate learning processes via computers, the internet, smartphones, Tablets, etc. There are clearly many advantages to using these technologies and to their effect on actual teaching and learning. One important benefit evident in such courses is overcoming time and distance problems, namely, it is possible to hold a class both in real time and retrospectively. Moreover, mediated teaching exists on two axes:

1. The course's degree of computerization, whether the system enables two-sided communication between the lecturer and the student, through sound, text, or video.

2. The synchronous axis, on which a course takes place simultaneously with other factors with coordination of times, and the asynchronous axis on which a course takes place at changing and irregular times (Livni and Yair, 2014).

Comparative studies conducted in the past regarding frontal teaching and computer-mediated teaching focused on two learning environments from students' perspectives. These studies emphasized courses taught by lecturers and tried to examine how students evaluate the different types of teaching and, in addition, how the teacherstudent interaction is expressed in the structure of the lessons. The findings that arose from this study indicate a slight advantage in attitudes to teaching in favor of computer-mediated lessons (Beyth-Marom et al., 2005).

\subsection{Elements Concerning Learning Perceptions and Learning Styles}

Other important teaching elements are the cognitive, emotional, and social aspects of learning perceptions and learning styles of schoolchildren, whether visual or verbal. These aspects were examined in a one-to-one model of technology, aimed at enhancing students' skills. This model was implemented in practice and led to a sharp rise in laptop use among students and teachers (Blau and Peled, 2012; Spektor-Levy and Granot-Gilat, 2012). According to the model, utilizing computers encourages active learning, a rise in student motivation, and improvement of academic achievements in core subjects (Grimes and Warschauer, 2008; Silvernail, 2011).

The one-to-one model and the one-to-many model are both assessed by the perceptions of students themselves. Perceived learning has three sources: cognitive, emotional, and social (Caspi and Blau, 2011). The cognitive aspect emphasizes acquiring new knowledge and reaching new insights, the emotional aspect examines feelings and experiences during the learning process and finally, the social aspect emphasizes enjoyment of interpersonal interactions during class. The difference between these three aspects is evident in the one-to-one model that emphasizes the student's potential, promoting active learning, and differential learning adapted to different academic levels. Furthermore, it focuses on the teacher-student relationship. All these are manifested in higher perceived learning than in the one-to-many model. Nonetheless, the one-to-many model has benefits for the teaching processes compared to teaching with no technology, as evident in the presentation of multimedia contents and in demonstrating processes, as well as access to many information sources and the ability to use technological means online from digital databases (Blau and Barzel-Rubin, 2013). The findings of previous studies (Davidovitch et al., 2016; Davidovitch and Yossel-Eisenbach, 2018) have shown that even in the early $21^{\text {st }}$ century, paper has not been relinquished and hence, it is precisely in academia that reading constitutes a teaching challenge as a research skill and the value of reference to research literature, while referring to the innovations of previous researchers. Nonetheless, the research findings indicate the development of digital reading and the changing learning habits of students - most of whom prefer to read from a screen than to print articles.

As stated, in the current study the researchers sought to examine whether and to what degree students' learning and reading habits in the digital generation are related to the shaping of their perceptions of teaching.

\section{Research Questions}

1. What are students' perceptions of the lecturer's role and of the academic teaching mode?

2. What variables shape students' perception of the lecturer's role and of the teaching mode? 


\section{Method}

\subsection{Research Population}

The study focused on undergraduate students in the 2016-2017 academic school year. The sample included a total of 772 students from 37 educational institutions and 14 disciplines.

The study consisted of approximately $66 \%$ women and $34 \%$ men. The mean age was 25 , approximately $43 \%$ from the Faculty of Social Sciences, the Humanities, and teaching, $7 \%$ from medicine and health professions as well as paramedical professions, $3.3 \%$ from the arts, $20.3 \%$ from business administration, economics, accounting, and law, 3.4\% from the natural sciences and the exact sciences, and $23 \%$ from the computer and engineering disciplines. Approximately $19 \%$ were studying at universities, $25.4 \%$ at non-government funded colleges, $54.4 \%$ at nonuniversity government funded institutions, and $1.3 \%$ at teachers' seminaries. Of all participants, $92.2 \%$ had laptops. 2.2. Research Procedure

The data were collected by a questionnaire distributed on the social networks by seminary students by means of a designated computer program in the 2016-2016 school year. In this way, it reached a wide audience of students and had a large response rate. The questionnaire was anonymous. It had four parts; the first part included demographic background features, the second part information on previous studies - high school, the third part questions on current studies, the fourth part questions on reading habits.

\subsection{Method of Analysis}

A. Statistical descriptive analysis: to examine the distribution of the research variables.

B. Linear regression: to examine the combined effect of social background features, high school study background, academic background, reading and learning habits, and the effect of the environment on shaping each of the two modes of teaching revealed in the factor analysis.

C. Factor analysis: secondary analysis aimed at reducing a large number of variables to a small number of variables that represent a shared content world, so that these can be entered in the various analyses. The chosen method, factor analysis performs confirmation in the Principal Component method using Varimax rotation. Construction of the variables was conducted by a weighted average of all the relevant statements and their merging in a single variable that denotes a shared content world. Utilizing this method, two variables were constructed: two perceptions of teaching modes.

\subsection{Description of the Variables}

\section{Dependent Variables}

The study includes two dependent variables that represent students' perceptions of academic teaching methods. Each variable is comprised of a group of statements that represent perceptions of teaching methods. Ranking is performed on a scale of five categories ranging from "completely unimportant" (1) to "extremely important" (5), where the statements are joined to form one variable following the factor analysis, by means of a weighted average of the statements that converged into the same content world.

Table-1. Loading of questionnaire items regarding perceptions of teaching methods on two factors.

\begin{tabular}{l|c|c}
\hline & $\begin{array}{c}\text { Personal frontal } \\
\text { teaching }\end{array}$ & $\begin{array}{c}\text { Teaching based on online learning } \\
\text { technologies }\end{array}$ \\
\hline I prefer computerized exams & 0.588 \\
\hline Class attendance is the basis for success in the course & 0.763 & 0.829 \\
\hline $\begin{array}{l}\text { Presentation of all the material to students in class is } \\
\text { the basis for their success in the course }\end{array}$ & 0.645 & 0.706 \\
\hline $\begin{array}{l}\text { The lecturer must focus on his role as a conveyor of } \\
\text { knowledge }\end{array}$ & 0.664 \\
\hline $\begin{array}{l}\text { I often watch video recordings of courses } \\
\text { Onine learning is better than learning in }\end{array}$ & & 0.643 \\
\hline $\begin{array}{l}\text { Integrating technologies and internet in the learning } \\
\text { process is essential }\end{array}$ & & \\
\hline
\end{tabular}

Table 1 presents the loadings of statements with regard to each of the manners in which students perceive academic teaching. It is evident that students perceive academic teaching in two ways: personal frontal teaching manifested in statements that present the lecturer as a teacher who conveys material directly, and thus the major significance of attendance, and teaching based on learning technologies, a perception that integrates statements presenting academic teaching based on e-learning and technology-assisted learning.

Accordingly, the study's two dependent variables were constructed:

1. Personal frontal teaching: a variable that includes three statements that converge into a content world representing a perception of personal frontal teaching, which are: "Class attendance is the basis for success in the course", "Presentation of all the material to students in class is the basis for their success in the course", "The lecturer must focus on his role as a conveyor of knowledge".

2. Teaching based on learning technologies: a variable that includes four statements that converge into a content world representing a perception of technology-based teaching, which are: "I prefer computerized exams", "I often watch video recordings of courses", "Online learning is better than learning in university/school classrooms",

"Integrating technologies and internet in the learning process is essential".

\section{Explanatory variables}

Social Background - Status Variables:

1. Respondent gender: Women (0) versus men (1). 
2. Mean parent education: Eight categories, each translated into an appraisal of mean years of education as follows: no education (4), elementary education (8), partial secondary (10), full secondary (12), non-academic post-secondary (13.5), Bachelor's degree (15), Master's degree (17), $\mathrm{PhD}(20)$. Then an average of the mother's and father's education was calculated.

Learning habits, a variable constructed based on the study conducted by Davidovitch and Yossel-Eisenbach (2018)

3. Combined learning habits: a combination of traditional and technological orientations

4. A traditional orientation to learning

5. A technology-resistant orientation

Reading habits, a variable constructed based on the study conducted by Davidovitch and Yossel-Eisenbach (2018)

6. Traditional reading habits

7. Online reading habits

8. Social environment: the influence of parents and teachers on learning

\section{Academic background - secondary studies}

9. Number of matriculation units completed in mathematics and English: constructed by summing the two variables: number of matriculation units completed in mathematics and number of matriculation units in English. The logic underlying selection of this variable is related to the claim of horizontal differences in the quality of matriculation certificates between high school graduates. A high quality matriculation certificate includes an increased level of English and mathematics studies, and therefore this variable might serve as an indication of study abilities in high school (Ayalon and Yogev, 1997).

\section{Academic background}

10. Discipline: Study disciplines were grouped in two categories, with the guideline being verbal disciplines versus non-verbal disciplines (1) Engineering and the natural and life sciences, (0) Social sciences and the humanities, including teaching, law, medicine, and health disciplines.

11. Study institutions: (1) University (0) College

\section{Findings}

3.1. Descriptive Analysis of the Research Variables

The findings indicate that students perceive the ideal academic teaching as belonging to one of two methods. One is personal frontal teaching and the other is technology-oriented teaching.

The findings reveal Table 2 that the teaching pattern with the highest mean significance as perceived by students $\mathrm{M}=3.6$ is the personal frontal pattern, versus a relatively low preference for the technological teaching pattern, which reached a mean of $\mathrm{M}=2.3$.

Table-2. Distribution of the significance of teaching patterns.

\begin{tabular}{c|c|c}
\hline Teaching method & Mean & $\mathbf{N}$ \\
\hline Personal-frontal & 3.6 & 445 \\
& $(0.95)$ & \\
\hline Technology-oriented & 2.3 & 438 \\
& $(0.87)$ & \\
\hline
\end{tabular}

\begin{tabular}{|c|c|c|}
\hline Variables & Mean & $\mathbf{N}$ \\
\hline $\begin{array}{l}\text { Number of matriculation units completed in English and } \\
\text { mathematics }\end{array}$ & $\begin{array}{c}8.6 \\
(1.5)\end{array}$ & 651 \\
\hline Mean parent education & $\begin{array}{l}13.6 \\
(2.4)\end{array}$ & 675 \\
\hline Combined learning habits: technological and traditional & $\begin{array}{c}2.406 \\
(0.971)\end{array}$ & 431 \\
\hline Traditional learning habits & $\begin{array}{c}2.955 \\
(1.135)\end{array}$ & 444 \\
\hline Technology-resistant learning habits & $\begin{array}{c}3.645 \\
(0.753) \\
\end{array}$ & 444 \\
\hline Traditional reading & $\begin{array}{c}2.541 \\
(0.948)\end{array}$ & 452 \\
\hline Online reading & $\begin{array}{c}3.02 \\
(1.14) \\
\end{array}$ & 455 \\
\hline Influence of the environment, parents and lecturers & $\begin{array}{c}2.45 \\
(0.848)\end{array}$ & 452 \\
\hline
\end{tabular}

The findings in Table 3 show that the mean of students' parents' education, $M=13.6$ years, is less than academic (15 years) but on average more than 12 school years. Namely, on average it is higher than secondary education. The number of English and mathematics units is 8.6, namely, higher than the minimum required for admission to academic studies, which is 5 units in English and 3 in mathematics. 
With regard to students' learning habits, the learning habit that reached the highest mean $(\mathrm{M}=3.64)$ appears to be the habit of resisting learning technologies, while the reading habit that reached the highest mean $(\mathrm{M}=3.02)$ was online reading.

\subsection{Perceptions of Teaching Methods}

Table 4 indicates that the majority of the respondents were female. The most common study disciplines were the non-technological disciplines and most of the students were college students.

Combined effect of features of social background, academic background, reading and learning habits, and the influence of the environment on shaping perceptions of academic teaching

Table-4. Distribution of gender, study disciplines, and study institutions.

\begin{tabular}{l|c|c}
\hline \multicolumn{2}{l}{$\begin{array}{l}\text { Variables } \\
\text { N }\end{array}$} & Percentage \\
\hline Gender & 235 & 34.1 \\
\hline Male & 455 & 65.9 \\
\hline Female & 690 & 100 \\
\hline Total & & 27.7 \\
\hline Study discipline & 153 & 72.3 \\
\hline Technological & 399 & 100 \\
\hline Other & 552 & 18.9 \\
\hline Total & & 81.1 \\
\hline Study institution & 146 & 100 \\
\hline College & 626 & \\
\hline Total & 772 & \\
\hline
\end{tabular}

Table-5. Coefficients (SE) of the combined effect of features of social background, study background in high school, academic background, and the influence of the environment on shaping students' perceptions of teaching

\begin{tabular}{|c|c|c|}
\hline Variables & $\begin{array}{c}\text { Perception of frontal- } \\
\text { personal teaching }\end{array}$ & $\begin{array}{c}\text { Perception of technology- } \\
\text { based teaching }\end{array}$ \\
\hline Gender (Male) & $\begin{array}{l}-0.016 \\
(0.111) \\
\end{array}$ & $\begin{array}{c}0.327 * * * \\
(0.327) \\
\end{array}$ \\
\hline Parents' education & -0.032 & $\begin{array}{l}-0.009 \\
(0.018) \\
\end{array}$ \\
\hline English and mathematics units & $\begin{array}{l}-0.020 \\
(0.022)\end{array}$ & $\begin{array}{l}-0.001 \\
(0.032)\end{array}$ \\
\hline $\begin{array}{l}\text { Study discipline } \\
\text { (technological) }\end{array}$ & $\begin{array}{l}0.282^{*} \\
(0.118)\end{array}$ & $\begin{array}{c}0.309 * * \\
(0.097)\end{array}$ \\
\hline Study institution (university) & $\begin{array}{l}-0.178 \\
(0.111)\end{array}$ & $\begin{array}{c}0.107 \\
(0.091)\end{array}$ \\
\hline Technology-resistant learning & $\begin{array}{l}-0.043 \\
(0.070)\end{array}$ & $\begin{array}{c}0.219^{* * *} \\
(0.057) \\
\end{array}$ \\
\hline Integrative learning & $\begin{array}{c}0.043 \\
(0.051) \\
\end{array}$ & $\begin{array}{c}0.051 \\
(0.042) \\
\end{array}$ \\
\hline Traditional learning & $\begin{array}{c}0.025 \\
(0.044)\end{array}$ & $\begin{array}{c}0.154 * * * \\
(0.037) \\
\end{array}$ \\
\hline Traditional reading & $\begin{array}{l}-0.054 \\
(0.053) \\
\end{array}$ & $\begin{array}{c}0.079 \\
(0.044) \\
\end{array}$ \\
\hline Online reading & $\begin{array}{l}-0.083 \\
(0.044) \\
\end{array}$ & $\begin{array}{c}0.052 \\
(0.036) \\
\end{array}$ \\
\hline $\begin{array}{l}\text { Environment - teachers and } \\
\text { parents }\end{array}$ & $\begin{array}{c}0.107 \\
(0.063)\end{array}$ & $\begin{array}{c}0.074 \\
(0.052)\end{array}$ \\
\hline Constant & $\begin{array}{c}4.293 * * * \\
(0.482)\end{array}$ & $\begin{array}{c}0.272 \\
(0.399) \\
\end{array}$ \\
\hline R square & 0.060 & 0.240 \\
\hline $\mathrm{N}$ & 377 & 373 \\
\hline
\end{tabular}

It appears that the shaping of students' perceptions of personal-frontal teaching Table 5 is significantly related to study discipline only. Namely, students of technological study disciplines tend to form a personal frontal perception of teaching, versus their peers from non-technological disciplines. All the other explanatory variables were unrelated to shaping perceptions of personal-frontal teaching.

Shaping technological teaching perceptions is related Table 5 to gender (men), study discipline (technological), traditional learning, and technology-resistant learning. Namely, male more than female students are inclined to develop a technologically oriented perception of teaching. Students of technological disciplines are more inclined to develop a technologically oriented perception of teaching than their peers who study non-technological disciplines. The more traditional students' learning patterns and the more resistant they are to technology-oriented learning, the more inclined they are to develop a perception of technological academic teaching. In other words, although students did not embrace technologically oriented learning patterns, according to their perception the ideal academic mode of teaching should be technological.

Reading habits appear to be unrelated to the shaping of teaching perceptions. 


\section{Conclusion and Discussion}

This study deals with student perceptions of the lecturer's role and of academic teaching modes, and the variables that shape their perceptions with regard to the lecturer's role and academic teaching modes.

The research findings indicate that students perceive academic teaching in two ways:

One is personal frontal teaching manifested in statements that present the lecturer as a teacher who conveys the material directly and hence the major significance of attendance.

Second - technology-based teaching, an approach that includes statements presenting academic teaching as based on e-learning and supported by technology.

With regard to students' learning habits, the learning habit that reached the highest mean $(\mathrm{M}=3.64)$ appears to be one that reflects resistance to learning technologies, while the reading pattern that reached the highest mean $(\mathrm{M}=3.02)$ was online reading (Davidovitch and Yossel-Eisenbach, 2018).

With regard to the shaping of a personal frontal perception of teaching, it is significantly associated only with study discipline. Namely, students in technological disciplines tend to formulate a personal frontal perception of teaching more than their peers in non-technological disciplines. All the other explanatory variables were not associated with the shaping of a personal frontal perception of teaching.

These findings entail a certain paradox. It would be expected that students who study technological disciplines in academia would develop a perception of academic teaching that is oriented towards learning technologies rather than towards personal frontal teaching. A possible explanation may be the significance of students' academic-social climate, as evident from previous research (Kurtz, 2014) as well as the significance that students ascribe to interpersonal interaction in class, as evident from the research conducted by Hativa (2015).

Moreover, male more than female students were found inclined to develop a perception of technological teaching. Students of technological disciplines were more inclined to develop a perception of technological teaching than their peers from non-technological disciplines. The more students held traditional learning patterns and resisted learning technologies the more inclined they were to develop a perception of technologically-oriented academic teaching. Reading habits appear to be unrelated to the shaping of teaching perceptions. These findings, together with that indicating that the perception to which students ascribed the most significance was personally oriented teaching, raise question marks. This is because a discrepancy is evident, since traditional and technologyresistant learning patterns were found to be associated with the shaping of perceptions favoring technologically oriented academic teaching. There is also a discrepancy between the preferences for personal frontal teaching although students are exposed to technology and active in it. A possible interpretation is that students indeed display a technologically resistant and traditional pattern of learning, but at the same time, they also think that academic teaching should be progressive and based on learning technologies.

A possible explanation may be students' expectation that academia will help them advance to the technological era while maintaining personally oriented teaching. Due to the nature of the data, these questions cannot be answered in the current study, rather only in further research that will examine the topic from the social climate dimension.

Notably, technology may constitute a challenge for human-personal contact, an element that students are not willing to relinquish, as evident from many other studies (Davidovitch and Soen, 2010; Davidovitch and Casakin, 2015). The passing of time has not changed students' craving for human contact. In this respect, human nature has remained constant, despite the transitions over time and the gradual development of technological instruments.

\section{References}

Ayalon, H. and A. Yogev, 1997. Students, schools, and enrollment in science and humanity courses in israeli secondary education. Educational Evaluation and Policy Analysis, 19(4): 339-353.Available at: https://doi.org/10.3102/01623737019004339.

Barak, M., A. Lipson and S. Lerman, 2006. Wireless laptops as means for promoting active learning in large lecture halls. Journal of Research on Technology in Education, 38(3): 245-263.Available at: https://doi.org/10.1080/15391523.2006.10782459.

Beyth-Marom, R., K. Saporta and A. Caspi, 2005. Synchronous vs. Asynchronous tutorials: Factors affecting students' preferences and choices. Journal of Research on Technology in Education, 37(3): 245-262.Available at: https://doi.org/10.1080/15391523.2005.10782436.

Blau, I. and A. Barzel-Rubin, 2013. Assisting learning disabilities and empowering excellence by "clickers" and interactive whiteboards. 15th Biennial EARLI Conference for Research in Learning and Instruction. TUM School of Education, Technical University, Munich, Germany.

Blau, I. and Y. Peled, 2012. Teachers' openness to change and attitudes towards ICT: Comparison of laptop per teacher and laptop per student programs. Interdisciplinary Journal of E-Learning and Learning Objects, 8(1): 73-82.Available at: https://doi.org/10.28945/1728.

Brown, J.S., 2002. Growing up digital: How the web changes work, education, and the ways people learn. United States Distance Learning Association Journal, 6(2): 11-20.

Byrnes, N., 2015. Lessons from the digital classroom. MIT Technology Review, 118(5): 79-81.

Campbell, A.B. and R.P. Pargas, 2003. Laptops in the classroomm. SIGCSE Bull, 35(1): 98-102.

Caspi, A. and I. Blau, 2011. Collaboration and psychological ownership: How does the tension between the two influence perceived learning? Social Psychology of Education, 14(2): 283-298.Available at: https://doi.org/10.1007/s11218-010-9141-z.

Davidovitch, N. and H. Casakin, 2015. Academic social climate - a key aspect in architectural studies. International Journal of Art \& Design Education, 34(2): 237-248.Available at: https://doi.org/10.1111/jade.12009.

Davidovitch, N. and D. Soen, 2010. Supportive social-academic climate in online teaching as a key to perceived learning success. In D. Chen \& G. Kurtz (Eds.), IT, learning, and teaching. Or Yehuda: The College for Academic Studies. pp: 183-206.

Davidovitch, N., R. Yavich and E. Druckman, 2016. Don't throw out paper and pens yet: On the reading habits of students. Journal of International Education Research, 12(4): 129-144.Available at: https://doi.org/10.19030/jier.v12i4.9799.

Davidovitch, N. and Y. Yossel-Eisenbach, 2018. On technology and students' reading habits - and their pedagogical significance. International Journal of Current Innovation Research, 4(1A): 1005-1044.

Eitan, N., 2006. Adjustment to teaching and learning in a technology-assisted virtual environment. Dapei Yozma, 4: 36-55.

Feinmesser, A., 2000. Although you can't see eyes. Ha'aretz, E-Learning Supplement.October 1.

Gehlen-Baum, V. and A. Weinberger, 2012. Notebook or Facebook? How students actually use mobile devices in large lectures. In A Ravenscroft, S. Lindstaedt, C. D. Kloos, \& D. Hernández-Leo (Eds.), 21 st century learning for 21 st century skills. Berlin Heidelberg: Springer-Verlag, 7563: 103-112.

Goldstein, O., N. Waldman, B. Tesler, M. Shonfeld, B.A. Forkosh, Z. Zelkovich, N. Mor, I. Heilweil, L. Kozminsky and W.S. Zid an, 2012. Information and communication technologies (ICT) integration by teacher educators in Israeli colleges of education: The current state of affairs, 2008-2009. Dapim, 54: 20-67. 
Grimes, D. and M. Warschauer, 2008. Learning with laptops: A multi-method case study. Journal of Educational Computing Research, 38(3): 305-332.Available at: https://doi.org/10.2190/ec.38.3.d.

Hativa, N., 2015. What does the research say about good teaching and excellent teachers. Teaching in the Academia, 5: 42-61.

Idan, A., 2000. Guide to the 21 st century. Tel Aviv: Dionon.

Karniel, M., 2003. Online learning communities. Available from http://www.edu-negev.gov.il/tapuz/motytp/elr.

Kozma, R.B., 2003. Technology, innovation and educational change: A global perspective. Eugene, OR: ISTE.

Kraushaar, J.M. and D.C. Novak, 2010. Examining the affects of student multitasking with laptops during the lecture. Journal of Information Systems Education, $21(2):$ 241-251.

Kurtz, G., 2014. The college for academic studies, Or Yehuda (Derby), open university - Oranim - Kibbutz movement school of education. CHAIS Conference on the Study of Learning Technologies: Learning in a Technological Era. Open University and Shoham (Elearning Service). pp: 169-176.

Livni, E. and Y. Yair, 2014. Seeing beyond the horizon - a comparison between distance teaching types in Ofek lessons and frontal teaching styles at the Open University. In: Y. Eshet-Alkalai, A. Caspi, S. Eden, N. Geri, Y. Yair, \& Y. Kalman (Eds.), Learning in the technological era. Raanana: Open University. pp: 77-85.

Mifsud, L., I. Anders, A.I. Mørch and S. Lieberg, 2013. An analysis of teacher-defined activities with mobile technologies: Predecessor and successor tool use in the classroom. Learning, Media and Technology, 38(1): 41-56.Available at: https://doi.org/10.1080/17439884.2012.655746.

Mishar-Tal, H., J. Kurtz and A. Pietersa, 2012. Study group on Facebook - Can it be used as a substitute for a learning management system? In A. Alkalai, A. Caspi, S. Eden, N. Gary, Y. Yair, \& Y. Kalman (Eds.), CHAIS Conference on Learning Technologies Research 2012. Ra'anana: The Open University. pp: 175-182.

Prensky, M., 2001. Digital natives, digital immigrants part 1. On the Horizon, 9(5): 1-6.Available at: https://doi.org/10.1108/10748120110424843.

Royer, R., 1997. Teaching on the internet--creating a collaborative project. Learning \& Leading with Technology, 25(3): 6-1 1.

Silvernail, D.L., 2011. A middle school one-to-one laptop program. Maine: Maine Education Policy Research Institute.

Spektor-Levy, O. and Y. Granot-Gilat, 2012. The impact of learning with laptops in 1: 1 classes on the development of learning skills and information literacy among middle school students. Interdisciplinary Journal of E-Learning and Learning Objects, 8(1): 8396.Available at: https://doi.org/10.28945/1729.

Yan, Z., 2004. The psychology of e learning: Why, what, and how? In J. Bourne \& J. C. Moore (Eds.), Elements of quality online education: Into the mainstream. in the Sloan-C Series, 5: 286-296. 